\title{
ANALISIS METODE PENELITIAN PADA BIDANG CSR DI INDONESIA
}

\author{
ANALYSIS OF RESEARCH METHODS IN THE FIELD OF CSR IN INDONESIA
}

\section{Aprilia Rahmawati*), Beltien Hanny Pramasterina*), dan Doddy Setiawan*)}

${ }^{*}$ Fakultas Ekonomi dan Bisnis, Universitas Sebelas Maret

\author{
J1. Ir Sutami No. 36-A Kentingan, Surakarta, 57126, Indonesia
}

\begin{abstract}
The purpose of this study is to give a comprehensive picture about the development of Corporate Social Responsibility in accounting research in Indonesia. In this study, $C S R$ research development was traced through mapping articles published in 14 national accredited journals and 10 international journals which sourced from Emerald, Elsevier, Springer, and Wiley. The sample of this research is 81 articles which examine CSR in Indonesia for the period of 2008-2018. This study classifies articles based on research topic, research method, and the model used by the researchers. The research showed that most of the study about CSR in Indonesia discussed about firm size and profitability (as antecedent variable), firm performance (as consequence variable), and the examination and application of CSR practices in Indonesia This research also showed that analytical method is commonly used as the research method in this topic.
\end{abstract}

Keywords: corporate social responsibility, literature review, firm size, profitability, firm performance, analytical method

\begin{abstract}
Abstrak: Penelitian ini bertujuan memberikan gambaran komprehensif tentang perkembangan penelitian akuntansi mengenai Corporate Social Responsibility (CSR) di Indonesia. Metode "Charting the Field" digunakan untuk mengetahui dan memetakan perkembangan penelitian mengenai CSR di Indonesia. Metode ini memetakan artikel yang dipublikasikan dalam 14 jurnal berakreditasi nasional serta dari 10 jurnal berakreditasi internasional yang diambil dari 4 basis data, yaitu Emerald, Elsevier, Springer, dan Wiley. Sampel diperoleh sebanyak 81 artikel yang membahas mengenai CSR di Indonesia dengan periode pengamatan dari tahun 2008 sampai dengan 2018. Penelitian ini mengklasifikasikan artikel berdasarkan topik, metode penelitian dan model yang digunakan oleh peneliti. Topik yang paling banyak diteliti membahas mengenai ukuran perusahaan dan profitabilitas (sebagai variabel anteseden), kinerja perusahaan (sebagai variabel konsekuensi), serta pengujian dan penerapan praktik pengungkapan CSR. Penelitian ini menunjukkan bahwa metode penelitian yang paling banyak digunakan dalam topik ini adalah metode analitik.
\end{abstract}

Kata kunci: corporate social responsibility, ukuran perusahaan, profitabilitas, kinerja perusahaan, metode analitik

\footnotetext{
${ }^{1}$ Corresponding author:

Email: aprilia.r@student.uns.ac.id
} 


\section{PENDAHULUAN}

Sejak diadopsi di Majelis Umum Perserikatan BangsaBangsa pada bulan September 2015, Indonesia telah mendukung Tujuan Pembangunan Berkelanjutan (Bahuet and Sopacua, n.d.). Di dalamnya terdapat 17 tujuan yang secara keseluruhan bertujuan kehidupan yang lebih baik di Indonesia. Dalam situs Kementerian Lingkungan Hidup dan Kehutanan (Kementerian Lingkungan Hidup dan Kehutanan, 2018), Kepala Badan Litbang dan Inovasi Kementerian Lingkungan Hidup dan Kehutanan (BLI KLHK) menegaskan bahwa sejak awal Indonesia telah berada di garis depan dalam pembahasan Sustainable Consumption and Production (SCP) dan berkomitmen untuk melanjutkan peran aktifnya dengan terus memajukan pembangunan sambil menangani tantangan lingkungan. Menurut Gunawan and Tin (2018), perkembangan CSR di Indonesia menjadi hal yang sangat penting karena Indonesia menghadapi sejumlah masalah fundamental dalam mewujudkan Sustainable Development Goals (SDGs) yang harus dicapai pada tahun 2030. Masalahmasalah yang dimaksud yaitu pengentasan kemiskinan (poverty alleviation), hak asasi manusia (human rights), masalah kesehatan dan keselamatan lingkungan (health and environmental safety concerns), polusi dan limbah (pollution and waste), ketidakamanan sosial dan politik (social and political insecurity) dan kebutuhan untuk investasi asing langsung (the need for direct foreign investment) (Goyal, 2005; Raynard and Forstater, n.d.). Pentingnya peran CSR dalam berkelanjutan bisnis perusahaan menjadikan CSR diadopsi dalam strategi bisnis perusahaan (Djunaedi et al. 2015). Oleh karena itu, perusahaan yang berada di Indonesia perlu untuk ikut serta dalam pencapaian SDG yang dapat diimplementasikan melalui program Corporate Sustainability Reporting (CSR) perusahaan.

Sejalan dengan paparan di atas, penelitian mengenai pengungkapan CSR di Indonesia semakin menjadi sorotan. Hal ini didukung dengan banyaknya kasus yang terjadi dimana perusahaan tidak dapat memenuhi tanggungjawab sosialnya di tengah masyarakat. Pada tahun 2010 Burger King, Unilever, Nestle dan Kraft Foods memutuskan menghentikan pembelian minyak kelapa sawit yang diproduksi oleh Grup Sinar Mas. Alasan mereka adalah dugaan adanya perusakan hutan tropis yang membahayakan kehidupan satwa, mengurangi kemampuan penyerapan karbon dioksida yang merupakan salah satu penyebab utama perubahan iklim global yang lebih dikenal dengan global warming
(Tempo.co, 2010). Di Kabupaten Bandung Barat (KBB), ratusan warga Desa Gadobangkong, Kecamatan Ngamprah kembali berunjuk rasa di depan pabrik PT Ultra Jaya di Jalan Raya Gadobangkong No 131 pada Bulan September 2017. Warga berunjuk rasa lantaran bau limbah tercium di pemukiman warga dan menganggu ketenangan warga setempat (Haryanto, 2017).

Penelitian mengenai pengungkapan CSR telah banyak dilakukan baik di Indonesia, misalnya oleh Anggraeni and Djakman, (2017); Larasati and Hadi, (2011); Yuliana et al. (2008), maupun di luar negeri, seperti oleh Sofyani et al. (2012); Yudhiyati and Solihin, (2016). Penelitian-penelitian yang ada menghasilkan pengaruh yang beragam, baik dari segi anteseden maupun konsekuensi dari praktik pengungkapan CSR. Berdasarkan uraian di atas, peneliti termotivasi untuk meneliti tren pengungkapan CSR di Indonesia lebih lanjut dengan membahas artikel yang diperoleh baik dari jurnal terakreditasi nasional/memiliki izin ISSN oleh Kementerian Riset, Teknologi, dan Pendidikan Tinggi Republik Indonesia yang tersedia di laman http:// sinta2.ristekdikti.go.id/journals dan jurnal internasional yang diambil dari 4 academic publisher, yaitu Elsevier, Springer, dan Wileyyang merupakan 3 academic publisher besar di dunia, serta Emerald yang merupakan academic publisher yang berfokus pada penelitian di bidang bisnis dan manajemen. Pemahaman mengenai penelitianpenelitian CSR di Indonesia secara keseluruhan masih kurang, masih banyak pengulangan mengenai topik yang dibahas sehingga tidak ada kebaharuan pada penelitian di bidang CSR. Sedangkan masih banyak topik-topik yang bisa dibahas lebih lanjut.

Pendekatan penyelesaian masalah pada penelitian ini berkaca dari penelitian yang dilakukan oleh (Hesford et al. 2007) mengenai penelitian bibliografi di bidang akuntansi manajemen, yaitu metode "Charting The Field". Metode ini digunakan untuk menganalisis dan memetakan perkembangan penelitian mengenai praktik pengungkapan CSR perusahaan selama tahun 2008-2018. Penelitian ini mengkategorikan artikel-artikel dengan tujuan agar pembaca dapat mengetahui lebih dalam mengenai perkembangan penelitian CSR di Indonesia selama 11 tahun terakhir. Manfaat dari penelitian ini adalah untuk memberikan gambaran kepada peneliti selanjutnya untuk mengevaluasi dan menganalisis lebih lanjut beberapa variabel, topik atau metode penelitian yang masih jarang dilakukan di Indonesia yang berkaitan dengan praktik pengungkapan CSR perusahaan. 


\section{METODE PENELITIAN}

Metode yang digunakan dalam penelitian ini adalah metode "Charting The Field" yang dikembangkan oleh Hesford et al. (2007). Model ini sebelumnya telah banyak digunakan di penelitian-penelitian terdahulu atas suatu tema. Beberapa diantaranya, penelitian yang dilakukan Suryaputra et al. (2017) terkait perkembangan penelitian kinerja perbankan; Suprianto dan Setiawan, (2017) terkait bibliografi manajemen laba; Dewi et al. (2018) terkait perkembangan penelitian di bidang pengungkapan di Indonesia; dan Herawati dan Bandi, (2019) terkait riset perpajakan dalam akuntansi baik di publikasi terakreditasi nasional maupun Simposium Nasional Akuntansi (SNA). Dalam pendekatan ini, peneliti memilih artikel penelitian mengenai praktik pengungkapan CSR perusahaan yang kemudian dikelompokkan berdasarkan topik, metode, dan disiplin ilmu.

Pemilihan jurnal-jurnal pada penelitian ini berdasarkan kriteria yang telah ditetapkan peneliti. Penelitian ini menggunakan data sekunder yang dapat diakses secara online yang diperoleh dari jurnal nasional maupun jurnal internasional. Artikel tersebut diambil dari 14 jurnal berakreditasi nasional/memiliki izin ISSN oleh Kementerian Riset, Teknologi, dan Pendidikan Tinggi Republik Indonesia yang tersedia di laman http:// sinta2.ristekdikti.go.id/journals. Pemilihan jurnal yang dilakukan oleh peneliti didasarkan pada jurnal terindeks SINTA Kementerian Riset, Teknologi, dan Pendidikan Tinggi Republik Indonesia kategori jurnal Sinta 1 yang telah terakreditasi A dan Sinta 2 yang telah terakreditasi B. Selain jurnal berakreditasi nasional peneliti juga menggunakan sampel/artikel dari 10 jurnal berakreditasi internasional yang diambil dari 4 academic publisher yaitu Elsevier, Springer, dan Wiley yang merupakan 3 academic publisher besar di dunia, serta Emerald yang merupakan academic publisher yang berfokus pada penelitian di bidang bisnis dan manajemen. Lokasi penelitian ini dilakukan di Indonesia pada tahun 2019.

Dalam menentukan sampel, berikut langkah-langkah yang dilakukan peneliti: Pertama, menentukan artikel yang dipublikasikan dalam kurun waktu 2008-2018 sebagai periode pengamatan. Kedua, membuka satu persatu portal jurnal terakreditasi tersebut dan mengetik kata kunci "Tanggung Jawab Sosial" atau "Corporate Social Responsibility" atau "CSR" atau "Corporate Social Responsibility Indonesia" atau "CSR Indonesia" pada kolom search. Ketiga, peneliti mengunduh setiap artikel yang ada di jurnal tersebut. Keempat, peneliti mengklasifikasikan artikel dalam sebuah tabulasi data berdasarkan judul, variabel, populasi dan sampel, hasil serta nama penulis dan tahun terbit.

Peneliti memperoleh 81 artikel dari 14 jurnal terakreditasi nasional dan 10 jurnal terakreditasi internasional yang telah memenuhi kriteria. Berikut daftar nama jurnal yang diperoleh sebagai sampel penelitian ini:

1. Gadjah Mada International Journal of Business (GMIJB) sebanyak 1 artikel (Hendarto, 2009)

2. Jurnal Akuntansi dan Keuangan (JAK) sebanyak 2 artikel (Cheng and Christiawan, 2011; Murwaningsari, 2009)

3. Jurnal Akuntansi dan Auditing Indonesia (JAAI) sebanyak 11 artikel (Agusti and Rahman, 2011; Arifin and Wardani, 2016; Barus and Maksum, 2011; Larasati and Hadi, 2011; Maraya and Yendrawati, 2016; Marfuah and Cahyono, 2011; Nugraheni and Permatasari, 2016; Rahman and Widyasari, 2008; Trisnawati, 2012; Wahyudi, 2017; Yudhiyati and Solihin, 2016)

4. Jurnal Akuntansi dan Keuangan Indonesia (JAKI) sebanyak 3 artikel (Anggraeni and Djakman, 2017; Nasution and Adhariani, 2016; Yuliana et al. 2008)

5. Jurnal Dinamika Akuntansi (JDA) sebanyak 4 artikel (Cahyonowati and Darsono, 2013; Fauziah and Yudho, 2013; Hermawan and Maf'ulah, 2014; Sofyani et al. 2012)

6. Jurnal Akuntansi Multiparadigma (JAMAL) sebanyak 4 artikel (Ibrahim et al. 2015; Lindawati and Puspita, 2015; Muchlis and Sukirman, 2016; Prihatiningtias, 2012)

7. Jurnal Ilmiah Akuntansi dan Bisnis (JIAB) sebanyak 12 artikel (Arimbawa and Wirakusuma, 2016; Armadi and Astika, 2016; Bulan and Astika, 2014; Kusumayanti and Astika, 2016; Prakasa and Astika, 2017; Putra and Wirakusuma, 2015; Putra et al. 2013; Ratih and Damayanthi, 2016; Sindhudiptha and Yasa, 2013; Suaryana, 2012; Susianti and Yasa, 2013; Wulandari et al. 2016)

8. Media Riset, Akuntansi, Auditing \& Informasi (MRAAI) sebanyak 4 artikel (Fahliyfi, 2014; Mayangsari and Aminah, 2013; Soedaryono and Riduifana, 2017; Suparjan and Mulya, 2012)

9. Jurnal Akuntansi dan Investasi (JAI) sebanyak 3 artikel (Junaidi, 2014; Nahar, 2015; Rahmawati, 2018)

10.Riset Akuntansi dan Keuangan Indonesia (RAKI) sebanyak 1 artikel (Palupi et al. 2017) 
11.Jurnal Akuntansi Bisnis (JAB) sebanyak 2 artikel (Anindita, 2014; Makhfudloh et al. 2018)

12.Jurnal Dinamika Manajemen (JDM) sebanyak 5 artikel (N. T. Handayani, 2012; Pebriana and Sukartha, 2012; Restuti and Nathaniel, 2012; Riantani and Nurzamzam, 2015; Wardoyo and Veronica, 2013)

13.Jurnal Keuangan dan Perbankan (JKP) sebanyak 11 artikel (Darwis, 2009; L. D. Handayani, 2012; Mai, 2017; Nussy, 2017, 2014; Restuningdiah, 2010a, 2010b; Suryaningsum et al. 2016; Susilawati et al. 2014; Suteja and Mayasari, 2017; Yasa et al. 2015)

14.Jurnal Akuntansi (JA) sebanyak 4 artikel (Anugerah et al. 2018; Gunawan, 2017; Setiyawati and Basar, 2017; Yanti, 2017)

15.Jurnal Ekonomi dan Bisnis (JEB) sebanyak 3 artikel (Eriandani, 2016; Sofiamira and Haryono, 2017; Witjaksono and Djaddang, 2018)

16. Social Responsibility Journal (SRJ) sebanyak 3 artikel (Arli and Tjiptono, 2014; Famiola and Adiwoso, 2016; Gunawan and Tin, 2018)

17.Journal of Financial Reporting and Accounting (JFRA) sebanyak 1 artikel (Amran et al. 2017)

18. International Journal of Islamic and Middle Eastern Finance and Management (IJIMEFM) sebanyak 1 artikel (Mirfazli, 2008)

19.Asian Journal of Accounting Research (AJAR) sebanyak 1 artikel (Isnalita and Narsa, 2017)

20.Journal of Agribusiness in Developing and Emerging Economies (JADEE) sebanyak 1 artikel (SjauwKoen-Fa et al. 2018)

21.Journal of Global Responsibility (JGR) sebanyak 1 artikel (Oeyono et al. 2011)

22.Journal of Cleaner Production (JCP) sebanyak 1 artikel (Joseph et al. 2016)
23.Journal of Business Ethics (JEB) sebanyak 1 artikel (Waagstein, 2011)

24. The American Anthropological Association sebanyak 1 artikel (Welker, 2009)

Tahap yang dilakukan berikutnya yaitu mengkasifikasikan penelitian-penelitian yang menjadi sampel berdasarkan beberapa kategori, yaitu topik pembahasan, populasi penelitian, dan metode penelitian. Peneliti melakukan klasifikasi kategori dengan tujuan memberikan pemahaman yang lebih baik mengenai penelitian-penelitan mengenai CSR di Indonesia.

\section{HASIL}

Corporate Social Responsibility (CSR) merupakan sebuah pendekatan bisnis yang memiliki pandangan untuk menghormati etika, orang-orang, masyarakat dan lingkungan, sebagai strategi integral yang meningkatkan posisi kompetitif dari sebuah perusahaan (Mittal et al. 2008). Keterlibatan perusahaan pada CSR berarti bahwa perusahaan membangun dan mempertahankan hubungan baik dengan seluruh stakeholder perusahaan. Dengan menjadikan CSR sebagai salah satu strategi, perusahaan bisa mendapatkan berbagai dampak yang baik seperti memaksimalkan shareholder value, meningkatkan reputasinya, dan memastikan kelangsungan jangka panjang perusahaan (Hsu and Chen, 2015). Hal tersebut dikarenakan perusahaan memperhatikan baik kepentingan perusahaan maupun stakeholder-nya, sehingga keputusan yang lebih baik tentang kegiatan CSR bisa dibuat (Burke and Logsdon, 1996).

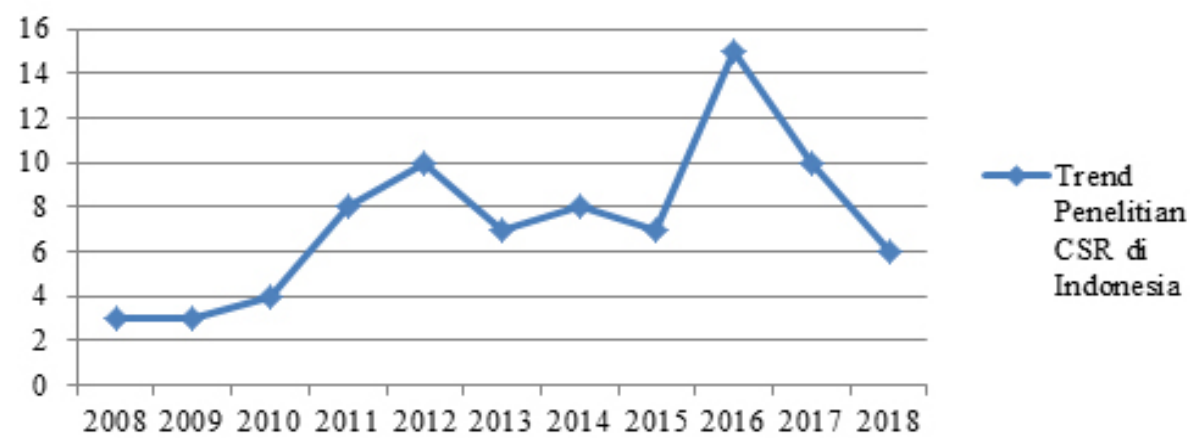

Gambar 1. Trend Penelitian CSR di Indonesia 
Peneliti menentukan periode 11 tahun sebagai periode pengamatan, yaitu dari tahun 2008 hingga 2018. Gambar 1 menunjukkan terjadinya kenaikan tren penelitian CSR di Indonesia selama tahun 2008 hingga 2018. Pada awal periode pengamatan (tahun 2008 dan tahun 2009) menunjukkan jumlah terendah dilakukannya penelitian yaitu sebanyak 3 artikel. Jumlah ini meningkat terus hingga tahun 2012, yaitu sebanyak 10 artikel. Pada tahun 2013 jumlah penelitian sempat mengalami penurunan menjadi 7 artikel. Penelitian kemudian kembali meningkat hingga tahun 2016. Tahun 2016 menunjukkan jumlah tertinggi tren penelitian CSR di Indonesia, yaitu sebanyak 15 artikel. Jumlah ini kemudian mengalami penurunan kembali pada tahun 2017 dan 2018, yaitu sebanyak 10 dan 6 artikel.

Berdasarkan Tabel 1, berikut sitasi dari setiap jurnal yang diteliti. Jurnal GMIJB memiliki 1 artikel dengan rata-rata sitasi sebesar 9, jurnal JAK memiliki 2 artikel dengan rata-rata sitasi sebesar 128, jurnal JAAI memiliki 11 artikel dengan rata-rata sitasi sebesar 6, jurnal JAKI memiliki 3 artikel dengan rata-rata sitasi sebesar 16, jurnal JDA memiliki 4 artikel dengan rata-rata sitasi sebesar 34, jurnal JAMAL memiliki 4 artikel dengan rata-rata sitasi sebesar 11, jurnal JIAB memiliki 12 artikel dengan rata-rata sitasi sebesar 6 , jurnal MRAAI memiliki 4 artikel dengan rata-rata sitasi sebesar 1, jurnal JAI memiliki 3 artikel dengan ratarata sitasi sebesar 0 , jurnal RAKI memiliki 1 artikel dengan rata-rata sitasi sebesar 0 , jurnal JAB memiliki 2 artikel dengan rata-rata sitasi sebesar 0 , jurnal JDM memiliki 5 artikel dengan rata-rata sitasi sebesar 11, jurnal JKP memiliki 11 artikel dengan rata-rata sitasi sebesar 4, jurnal JA memiliki 4 artikel dengan rata-rata sitasi sebesar 0, jurnal JEB memiliki 3 artikel dengan rata-rata sitasi sebesar 0 , jurnal SRJ memiliki 3 artikel dengan rata-rata sitasi sebesar 8 , jurnal JFRA memiliki 1 artikel dengan rata-rata sitasi sebesar 8 , jurnal IJIMEFM memiliki 1 artikel dengan rata-rata sitasi sebesar 50, jurnal AJAR memiliki 1 artikel dengan ratarata sitasi sebesar 0 , jurnal JADEE memiliki 1 artikel dengan rata-rata sitasi sebesar 0 , jurnal JGR memiliki 1 artikel dengan rata-rata sitasi sebesar 91, jurnal JCP memiliki 1 artikel dengan rata-rata sitasi sebesar 38, jurnal JBE memiliki 1 artikel dengan rata-rata sitasi sebesar 114, dan jurnal AAA memiliki 1 artikel dengan rata-rata sitasi sebesar 216 .
Tabel 1. Rata-rata Sitasi Tiap Jurnal

\begin{tabular}{|c|c|c|c|}
\hline $\begin{array}{l}\text { Nama } \\
\text { Jurnal }\end{array}$ & $\begin{array}{c}\text { Jumlah } \\
\text { Sitasi }\end{array}$ & $\begin{array}{l}\text { Jumlah } \\
\text { Artikel }\end{array}$ & $\begin{array}{c}\text { Rata-rata } \\
\text { Sitasi }\end{array}$ \\
\hline GMIJB & 9 & 1 & 9 \\
\hline JAK & 256 & 2 & 128 \\
\hline JAAI & 68 & 11 & 6 \\
\hline JAKI & 49 & 3 & 16 \\
\hline JDA & 136 & 4 & 34 \\
\hline JAMAL & 43 & 4 & 11 \\
\hline JIAB & 66 & 12 & 6 \\
\hline MRAAI & 4 & 4 & 1 \\
\hline JAI & 1 & 3 & 0 \\
\hline RAKI & 0 & 1 & 0 \\
\hline JAB & 0 & 2 & 0 \\
\hline JDM & 55 & 5 & 11 \\
\hline JKP & 48 & 11 & 4 \\
\hline JA & 0 & 4 & 0 \\
\hline JEB & 1 & 3 & 0 \\
\hline SRJ & 23 & 3 & 8 \\
\hline JFRA & 8 & 1 & 8 \\
\hline IJIMEFM & 50 & 1 & 50 \\
\hline AJAR & 0 & 1 & 0 \\
\hline JADEE & 0 & 1 & 0 \\
\hline JGR & 91 & 1 & 91 \\
\hline JCP & 38 & 1 & 38 \\
\hline JBE & 114 & 1 & 114 \\
\hline AAA & 216 & 1 & 216 \\
\hline Total Sitasi & 1276 & 81 & 16 \\
\hline
\end{tabular}

Tabel 1 menunjukkan bahwa jurnal yang paling banyak disitasi adalah jurnal AAA dengan jumlah dan rata-rata sitasi sebesar 216, kemudian JAK dengan jumlah sitasi sejumlah 256 dan rata-rata sebesar 128. Sedangkan jurnal yang paling sedikit disitasi adalah jurnal JAI, RAKI, JAB, JA, JEB, AJAR, JADEE dengan jumlah dan rata-rata sitasi sebesar 0 , hal ini dapat disebabkan karena jumlah artikel mengenai CSR di Indonesia dalam jurnal-jurnal tersebut masih sedikit. Total sitasi untuk seluruh artikel dalam penelitian ini adalah sejumlah 1276 sitasi dengan rata-rata 16 sitasi tiap artikelnya. Terdapat 8 jurnal yang memiliki rata-rata sitasi diatas rata-rata total yaitu jurnal JAK, JAKI, JDA, IJIMEFM, JGR, JCP, JBE, AAA dan terdapat 16 jurnal yang memiliki rata-rata sitasi dibawah rata-rata total yaitu jurnal GMIJB, JAAI, JAMAL, JIAB, MRAAI, JAI, RAKI, JAB, JDM, JKP, JA, JEB, SRJ, JFRA, AJAR, JADEE. Sehingga dapat disimpulkan bahwa sebagian besar artikel mengenai CSR di Indonesia masih memiliki sitasi di bawah rata-rata. 


\section{Klasifikasi berdasarkan Topik Pembahasan}

Pengklasifikasian artikel tentang CSR berdasarkan pada topik penelitian dibedakan menjadi 4 yaitu anteseden yang merupakan faktor-faktor yang memotivasi dilakukannya CSR, konsekuensi yang merupakan dampak dari aktivitas CSR maupun pengungkapannya yang dibahas oleh peneliti, anteseden, dan konsekuensi, dan klasifikasi lainnya yaitu topik selain ketiga klasifikasi yang telah disebutkan sebelumnya.

Tabel 2 menunjukkan empat klasifikasi artikel tentang CSR di Indonesia berdasarkan topik yang dibahas. Berdasarkan tabel, disimpulkan bahwa topik yang sering dibahas selama 11 tahun adalah selain topik anteseden dan konsekuensi (topik lainnya) yaitu sekitar 43\% (35 artikel) dimana detail mengenai topik penelitian bisa dilihat pada Tabel 7, sedangkan yang membahas mengenai konsekuensi adalah sekitar 28\% (23 artikel), anteseden adalah sebesar 19\% (15 artikel) dan yang membahas kombinasi antara antesedendan konsekuensi adalah sekitar 10\% (8 artikel). Jika dibandingkan antara periode 1 (tahun 2008-2012) dan periode 2 (tahun 2013-2018), telah terjadi peningkatan cukup signifikan pada topik yang membahas selain topik anteseden dan konsekuensi (topik lainnya), yaitu sekitar lebih dari 50\% (dari 12 artikel menjadi
23 artikel); serta topik konsekuensi yaitu meningkat lebih dari $100 \%$ dibanding dengan periode 1 (dari 5 artikel menjadi 18 artikel), sedangkan topik anteseden mengalami peningkatan dari 6 artikel menjadi 9 artikel saja. Namun untuk penelitian yang membahas tentang kombinasi anteseden dan konsekuensi mengalami penurunan dari 5 artikel menjadi 3 artikel.

Tabel 3 menjelaskan secara detail mengenai variabel anteseden apa saja yang dibahas olehpeneliti. Artikel yang memiliki topik anteseden yaitu 15 artikel dan dari jumlah tersebut yang membahas tentang variabel anteseden menggunakan variabel ukuran perusahaan dan profitabilitas merupakan variabel yang paling dominan dibahas yakni masing-masing sekitar $16 \%$ dari seluruh penelitian anteseden, sedangkan variabel leverage perusahaan berkisar $12 \%$. Variabel ukuran dewan komisaris dan konsentrasi kepemiliki masing-masing sebesar $7 \%$ sedangkan variabel profil perusahaan sebesar $5 \%$, serta variabel lainnya digunakan kurang dari 5\% dari seluruh penelitian. Jadi berdasarkan analisis diatas, dapat disimpulkan bahwa kebanyakan peneliti di Indonesia lebih banyak meneliti mengenai ukuran perusahaan, profitabilitas, dan leverage perusahaan yang menjadi faktor pelaksanaan maupun pengungkapan CSR di Indonesia.

Tabel 2. Klasifikasi Artikel berdasarkan Topik

\begin{tabular}{|c|c|c|c|c|c|c|}
\hline \multirow[t]{2}{*}{ Nama Jurnal } & \multicolumn{2}{|c|}{$2008 \mathrm{~s} / \mathrm{d} 2018$} & \multicolumn{2}{|c|}{$2008 \mathrm{~s} / \mathrm{d} 2012$} & \multicolumn{2}{|c|}{$2013 \mathrm{~s} / \mathrm{d} 2018$} \\
\hline & Jumlah & $\%$ & Jumlah & $\%$ & Jumlah & $\%$ \\
\hline Anteseden & 15 & $19 \%$ & 6 & $21 \%$ & 9 & $17 \%$ \\
\hline Konsekuensi & 23 & $28 \%$ & 5 & $18 \%$ & 18 & $34 \%$ \\
\hline Anteseden dan Konsekuensi & 8 & $10 \%$ & 5 & $18 \%$ & 3 & $6 \%$ \\
\hline Lainnya & 35 & $43 \%$ & 12 & $43 \%$ & 23 & $43 \%$ \\
\hline Total & 81 & & 28 & & 53 & \\
\hline
\end{tabular}

Tabel 7. Klasifikasi artikel berdasarkan metode penelitian

\begin{tabular}{lcccccc}
\hline Nama Jurnal & \multicolumn{2}{c}{$2008 \mathrm{~s} / \mathrm{d} 2018$} & \multicolumn{2}{c}{$2008 \mathrm{~s} / \mathrm{d} 2012$} & \multicolumn{2}{c}{$2013 \mathrm{~s} / \mathrm{d} 2018$} \\
\cline { 2 - 7 } & Jumlah & $\%$ & Jumlah & $\%$ & Jumlah & $\%$ \\
\hline Analytical & 63 & $78 \%$ & 23 & $82 \%$ & 40 & $75 \%$ \\
Review & 9 & $11 \%$ & 3 & $11 \%$ & 6 & $11 \%$ \\
Survey & 9 & $11 \%$ & 2 & $7 \%$ & 7 & $13 \%$ \\
\hline Total & 81 & & 28 & & 53 & \\
\hline
\end{tabular}


Tabel 4 menunjukkan variabel konsekuensi atau dampak dari aktivitas CSR maupun pengungkapan CSR yang dibahas oleh peneliti. Dari 23 artikel yang membahas mengenai CSR, dampak atau variabel yang paling sering dibahas adalah kinerja perusahaan sebesar 34\% (14 artikel), nilai perusahaan sebesar 24\% (10 artikel), earning response coefficient/ERC sebesar 12\% (5 artikel), return saham sebesar 7\% (3 artikel), dan agresivitas pajak sebesar 5\% (2 artikel). Sedangkan dampak atau variabel yang lainnya masing-masing hanya dibahas sebanyak 2\% (1 artikel).

Tabel 5 menunjukkan selain topik anteseden dan konsekuensi (topik lainnya) yang dibahas oleh peneliti mengenaik pengungkapan CSR di Indonesia. Topik lainnya ini biasanya dilakukan dengan menganalisis aktivitas CSR maupun pengungkapan CSR perusahaan pada kondisi tertentu, atau mengonstruksi indikator CSR seperti mencoba membandingkan atau melakukan studi komparasi bagaimana pengungkapan CSR antar tahun tertentu, negara satu dengan yang lainnya atau antara perusahaan dengan yang lainnya. Penggunaan informasi CSR maupun pengungkapan CSR sebagai variabel intervening dan moderating oleh peneliti juga termasuk dalam topik lainnya. Dari 35 artikel yang membahas topik lainnya, topik pengujian dan penerapan serta studi komparasi dari pengungkapan CSR di Indonesia adalah yang paling dominan untuk diteliti yaitu sebanyak 8 artikel, kemudian disusul dengan variabel moderasi 7 artikel, variabel intervening dan pemaknaan masing-masing sebanyak 4 artikel dan 3 artikel, korelasi dan literature review masing-masing sebanyak 2 artikel. Sedangkan pengukuran indeks hanya digunakan sebanyak 1 artikel.

Tabel 3. Klasifikasi Variabel Anteseden

\begin{tabular}{|c|c|c|c|c|c|}
\hline \multirow{2}{*}{ Variabel Anteseden } & \multirow{2}{*}{ Jumlah } & \multirow{2}{*}{$\%$} & \multicolumn{3}{|c|}{ Pengaruh } \\
\hline & & & Positif & Negatif & Tidak \\
\hline Ukuran Perusahaan & 12 & $16 \%$ & 8 & 1 & 3 \\
\hline Profitabilitas & 12 & $16 \%$ & 3 & 1 & 8 \\
\hline Leverage Perusahaan & 9 & $12 \%$ & 2 & - & 3 \\
\hline Ukuran Dewan Komisaris & 5 & $7 \%$ & - & 4 & 5 \\
\hline Konsentrasi Kepemilikan & 5 & $7 \%$ & 4 & - & - \\
\hline Profil Perusahaan & 4 & $5 \%$ & 3 & - & 2 \\
\hline Umur Perusahaan & 3 & $4 \%$ & 1 & - & 2 \\
\hline Kepemilikan Manjerial & 3 & $4 \%$ & - & - & 2 \\
\hline Likuiditas Perusahaan & 2 & $3 \%$ & - & - & 1 \\
\hline Kepemilikan Institusional & 2 & $3 \%$ & 1 & - & 2 \\
\hline Penggunaan Laporan CSR yang berdiri sendiri & 2 & $3 \%$ & - & 1 & 1 \\
\hline Penggunaan Jasa Asurans Eksternal & 2 & $3 \%$ & - & - & 2 \\
\hline Pengadopsi GRI & 2 & $3 \%$ & - & 1 & 1 \\
\hline Status Perusahaan & 1 & $1 \%$ & - & - & 1 \\
\hline Slack Resources & 1 & $1 \%$ & 1 & - & - \\
\hline Rasio Efisiensi Operasi & 1 & $1 \%$ & 1 & 1 & - \\
\hline Proporsi Dewan Komisaris Independen & 1 & $1 \%$ & 1 & - & - \\
\hline Latar belakang pendidikan dewan komisaris & 1 & $1 \%$ & 1 & - & - \\
\hline Komposisi Dewan Direksi & 1 & $1 \%$ & 1 & - & - \\
\hline Kinerja Sosial & 1 & $1 \%$ & 1 & - & - \\
\hline Kinerja Lingkungan & 1 & $1 \%$ & - & - & 1 \\
\hline Kinerja Keuangan & 1 & $1 \%$ & 1 & - & - \\
\hline Gross Earning & 1 & $1 \%$ & 1 & - & - \\
\hline Feminisme Dewan Komisaris & 1 & $1 \%$ & - & - & 1 \\
\hline Dewan Komisaris Wanita & 1 & $1 \%$ & 1 & - & - \\
\hline Bank Pendukung & 1 & $1 \%$ & 1 & - & - \\
\hline
\end{tabular}


Tabel 4. Klasifikasi Variabel Konsekuensi

\begin{tabular}{|c|c|c|c|c|c|}
\hline \multirow{2}{*}{ Variabel Anteseden } & \multirow{2}{*}{ Jumlah } & \multirow{2}{*}{$\%$} & \multicolumn{3}{|c|}{ Pengaruh } \\
\hline & & & Positif & Negatif & Tidak \\
\hline Kinerja Perusahaan & 14 & $34 \%$ & 7 & 1 & 6 \\
\hline Nilai Perusahaan & 10 & $24 \%$ & 6 & 2 & 2 \\
\hline ERC & 5 & $12 \%$ & 3 & - & 2 \\
\hline Imbal Hasil Saham/Return Saham & 3 & $7 \%$ & 3 & - & - \\
\hline Agresivitas Pajak & 2 & $5 \%$ & 1 & - & 1 \\
\hline Volume Perdagangan & 1 & $2 \%$ & 1 & - & - \\
\hline Reputasi perusahaan & 1 & $2 \%$ & 1 & - & - \\
\hline Price to Book Value & 1 & $2 \%$ & 1 & - & - \\
\hline Penghindaran Pajak & 1 & $2 \%$ & 1 & - & - \\
\hline Harga Saham & 1 & $2 \%$ & - & - & 1 \\
\hline Daya Saing & 1 & $2 \%$ & - & - & 1 \\
\hline Kualitas Laba & 1 & $2 \%$ & 1 & - & - \\
\hline
\end{tabular}

Tabel 5. Klasifikasi Topik Lainnya

\begin{tabular}{lc}
\hline Topik Lainnya & Jumlah \\
\hline Pengujian dan Penerapan & 8 \\
Komparasi & 8 \\
Variabel Moderasi & 7 \\
Variabel Intervening & 4 \\
Pemaknaan & 3 \\
Korelasi & 2 \\
Literature Review & 2 \\
Pengukuran Indeks & 1 \\
\hline
\end{tabular}

\section{Klasifikasi berdasarkan Populasi Penelitian}

Tabel 6 menunjukkan bahwa dari 81 artikel yang diteliti, populasi yang paling dominan diteliti adalah seluruh perusahaan publik yang terdaftar di Bursa Efek Indonesia yaitu sebanyak 16 artikel, sedangkan sisanya berfokus pada perusahaan-perusahaan sektor tertentu yang terdaftar di Bursa Efek Indonesia seperti perusahaan manufaktur sebanyak 9 artikel, perusahaan pertambangan sebanyak 7 artikel perusahaan perbankan dan perbankan syariah masing-masing sebanyak 6 artikel dan 5 artikel, perusahaan property dan real estate, serta perusahaan sumber daya alam masing-masing sebanyak 3 artikel, dan 2 artikel. Kemudian artikel lainnya menggunakan populasi yang lebih spesifik. Dikarenakan banyaknya jumlah artikel yang memiliki topik pengujian dan penerapan, hal ini membuat jenis populasi penelitian CSR di Indonesia menjadi lebih beragam dengan jumlah total 37 klasifikasi populasi penelitian.

\section{Klasifikasi Artikel berdasarkan Metode Penelitian}

Metode penelitian yang digunakan oleh para peneliti untuk meneliti praktik pengungkapan CSR perusahaan di Indonesia diklasifikasikan berdasarkan pada 3 metode penelitian yaitu metode analytical, metode literature review dan metode survei. Metode analytical adalah para peneliti menggunakan berbagai teknik analisis data baik regresi berganda, analisis deskriptif, content analysis dengan menggunakan berbagai alat misalnya SPSS, SEM, E-Views dan Amos untuk menguji hubungan antar variabel. Metode literature review, yaitu dengan melakukan perbandingan atau studi kasus mengenai laporan keuangan dan pengujian kembali indeks serta teori oleh peneliti. Metode survey, yaitu dengan melakukan penyebaran kuesioner oleh peneliti dengan skala likert untuk mengetahui persepsi penyedia laporan keuangan dan pemaknaan laporan keuangan. Dapat disimpulkan bahwa dalam kurun waktu 11 tahun (2008-2018) metode penelitian yang banyak digunakan oleh peneliti di Indonesia adalah metode analytical, yaitu sekitar 78\% (63 artikel) dari seluruh artikel mengenai CSR yang direview, sedangkan artikel yang menggunakan metode literature review dan survey masing-masing yaitu $11 \%$ ( 9 artikel) dan $11 \%$ (9 artikel). Jika dilihat baik pada periode 1 (2008-2012) maupun periode 2 (2013-2018) penelitian mengenai CSR di Indonesia sebagian besar masih menggunakan metode analytical, yaitu sekitar $82 \%$ (23 artikel) dan 75\% (40 artikel). Untuk penelitian dengan metode literature review dan survey terdapat peningkatan jumlah penelitian pada periode 2 yang awalnya berjumlah $18 \%$ menjadi $24 \%$ dari jumlah keseluruhan artikel. 
Tabel 6. Klasifikasi Populasi Penelitian

\begin{tabular}{|c|c|}
\hline Populasi & Jumlah \\
\hline Seluruh perusahaan yang terdaftar di BEI & 16 \\
\hline Perusahaan Manufaktur & 9 \\
\hline Perusahaan Pertambangan & 7 \\
\hline Perusahaan Perbankan & 6 \\
\hline Perusahaan Perbankan Syariah & 5 \\
\hline Perusahaan Property dan Real Estate & 3 \\
\hline Perusahaan Sumber Daya Alam & 2 \\
\hline $\begin{array}{l}\text { Perusahaan Perbankan Syariah Indonesia dan } \\
\text { Malaysia }\end{array}$ & 2 \\
\hline Perusahaan Non Keuangan & 1 \\
\hline Perusahaan yang terdaftar di DES & 1 \\
\hline Perusahaan Perbankan Syariah di dunia & 1 \\
\hline Perusahaan Tambang dan Kelapa Sawit & 1 \\
\hline Perusahaan Rokok & 1 \\
\hline Perusahaan Food and Beverage & 1 \\
\hline $\begin{array}{l}\text { Perusahaan manufaktur, pertambangan dan } \\
\text { pertanian }\end{array}$ & 1 \\
\hline Badan Usaha Milik Negara (BUMN) & 1 \\
\hline Perusahaan Go Public di JII & 1 \\
\hline Perusahaan High Profile & 1 \\
\hline Perusahaan Furniture di Jepara & 1 \\
\hline Korban bencana alam & 1 \\
\hline Masyarakat Daerah Luwu & 1 \\
\hline Masyarakat Kota Surakarta & 1 \\
\hline $\begin{array}{l}\text { Best Corporate Citizen oleh KLD Research and } \\
\text { Analytics }\end{array}$ & 1 \\
\hline Nasabah BPR Denpasar & 1 \\
\hline Top 50 Indonesian listed corporations & 1 \\
\hline Customer in Yogyakarta, Indonesia & 1 \\
\hline $\begin{array}{l}\text { Manufacture, Infrastructure, and Service } \\
\text { Companies That Listed at Indonesia Stock } \\
\text { Exchange }\end{array}$ & 1 \\
\hline $\begin{array}{l}\text { BUMN dan non BUMN yang terdaftar di Bursa } \\
\text { Efek Indonesia }\end{array}$ & 1 \\
\hline $\begin{array}{l}\text { Food-manufacturing MNCs operating in } \\
\text { Indonesia }\end{array}$ & 1 \\
\hline $\begin{array}{l}\text { Best practice companies in Malaysia and } \\
\text { Indonesia }\end{array}$ & 1 \\
\hline Islamic banks in Malaysia and Indonesia & 1 \\
\hline $\begin{array}{l}\text { Semua perusahaan di Indonesia yang } \\
\text { menyajikan laporan keberlanjutan tahun } 2014\end{array}$ & 1 \\
\hline $\begin{array}{l}\text { CSR research in the accounting area in } \\
\text { Indonesia }\end{array}$ & 1 \\
\hline $\begin{array}{l}\text { Smallholder sourcing model were Unilever's } \\
\text { black soybean supply chain in Java/Indonesia } \\
\text { and its tomato supply chain in Maharashtral } \\
\text { India. }\end{array}$ & 1 \\
\hline $\begin{array}{l}\text { All companies listed on the IDX except natural } \\
\text { resources companies }\end{array}$ & 1 \\
\hline
\end{tabular}

\section{Karakteristik Jurnal}

Pada bagian ini akan dijelaskan pengelompokan jurnal mengenai praktik pengungkapan CSR perusahaan berdasarkan topik dan metode penelitian. Tabel 8 menunjukkan proporsi topik penelitian dari karakteristik jurnal yang dibuat oleh peneliti di Indonesia. Untuk topik penelitian anteseden mengenai praktik pengungkapan CSR perusahaan terdapat 15 artikel pada jurnal JAAI, JAKI, JDA, JIAB, JDM, JKP, JA, dan SRJ masingmasing sebesar $27 \%, 13 \%, 7 \%, 13 \%, 13 \%, 13 \%, 7 \%$ dan $7 \%$. Sedangkan untuk topik penelitian konsekuensi mengenai praktik pengungkapan CSR perusahaan terdapat 25 artikel pada jurnal GMIJB, JAK, MRAAI, RAKI, dan AJAR masing-masing 4\%, pada jurnal JAAI, JAB, JDM, JKP, JEB, dan PSBS masing-masing $8 \%$, kemudian pada jurnal JA sebesar $12 \%$, serta pada jurnal JIAB sebesar $20 \%$.

Untuk topik penelitian anteseden dan konsekuensi mengenai praktik pengungkapan CSR perusahaan hanya terdapat total 8 artikel pada jurnal JAAI, JAKI, JAMAL, MRAAI masing-masing 13\% (1 artikel) serta JIAB dan JKP masing-masing 25\% (2 artikel). Sedangkan topik penelitian lainnya dari praktik pengungkapan CSR perusahaan terdapat total 35 artikel pada jurnal JAK, JDM, JEB, JFRA, IJIMEFM, JADEE, JGR, JCP, JCB, dan AAA masing-masing sebesar 3\%, MRAAI dan SRJ sebesar 6\%, JDA, JAMAL, JIAB, dan JAI masing-masing sebesar $9 \%$, JAAI sebesar $11 \%$, dan JKP sebesar 14\%.

Tabel 9 menunjukkan proporsi metode penelitian dari karakteristik tiap jurnal yang diteliti. Untuk metode penelitian analytical pada jurnal JIAB, JAAI, JKP, JDM, JDA, MRAAI, JA, JAKI, JAK, JEB, JAMAL, RAKI, JAB, IJIMEFM, AJAR, JGR, dan JCP masingmasing sebesar $19 \%, 16 \%, 16 \%, 8 \%, 6 \%, 6 \%, 6 \%$, $5 \%, 3 \%, 3 \%$, dan sisanya masing-masing sebesar $2 \%$. Sedangkan penggunaan metode literature review dan survey masing-masing hanya terdapat 9 artikel. Metode literature review dalam artikel diterbitkan di jurnal JAMAL dan SRJ masing-masing 2 artikel dan pada jurnal JAAI, JFRA, JADEE, JBE, dan AAA masing-masing 1 artikel. Untuk metode penelitian survey yang diterbitkan di jurnal JAI sebanyak 3 artikel dan pada jurnal GMIJB, JAMAL, JAB, JKP, JEB, SRJ, dan masing-masing hanya 1 artikel. Jadi bisa disimpulkan bahwa hampir semua artikel pada jurnal yang direview menggunakan metode analytical dalam penelitian, dari 24 jurnal hanya terdapat 7 jurnal yang 
tidak menggunakan metode analytical. Perbedaan karakteristik jurnal berdasarkan metode penelitian yang digunakan ini bisa jadi dikarenakan terbatasnya jumlah artikel mengenai CSR dalam jurnal tersebut, beberapa jurnal hanya memiliki 1 artikel mengenai CSR.

\section{Implikasi Manajerial}

Studi ini memiliki beberapa implikasi teoritis yaitu studi ini bisa dijadikan sebagai acuan bagi peneliti-peneliti yang akan membahas topik CSR, dengan adanya studi ini peneliti selanjutnya dapat mempertimbangkan topik-topik lain yang berhubungan dengan CSR namun masih kurang diteliti maupun meneliti hal yang belum dieksplorasi sebelumnya. Dengan melakukan studi lebih lanjut dalam lingkup yang lebih luas, pemahaman mengenai CSR bisa lebih diperdalam. Dalam penerapannya studi ini memiliki implikasi yaitu untuk membuktikan bahwa banyak studi yang dilakukan telah membuktikkan bahwa terdapat manfaat yang baik apabila perusahaan melakukan dan menerapkan CSR dengan baik seperti meningkatnya kinerja perusahaan dan nilai perusahaan. Dengan adanya bukti-bukti tersebut maka perusahaan bisa terdorong untuk menerapkan CSR dengan lebih baik lagi.

Tabel 8. Klasifikasi Jurnal berdasarkan Topik Penelitian

\begin{tabular}{|c|c|c|c|c|c|c|c|c|c|}
\hline \multirow[b]{2}{*}{ Nama Jurnal } & \multicolumn{8}{|c|}{ Topik Penelitian } & \multirow[b]{2}{*}{ Total } \\
\hline & Anteseden & $\%$ & Konsekuensi & $\%$ & $\begin{array}{l}\text { Anteseden dan } \\
\text { Konsekuensi }\end{array}$ & $\%$ & Lainnya & $\%$ & \\
\hline GMIJB & 0 & $0 \%$ & 1 & $4 \%$ & 0 & $0 \%$ & 0 & $0 \%$ & 1 \\
\hline JAK & 0 & $0 \%$ & 1 & $4 \%$ & 0 & $0 \%$ & 1 & $3 \%$ & 2 \\
\hline JAAI & 4 & $27 \%$ & 2 & $9 \%$ & 1 & $13 \%$ & 4 & $11 \%$ & 11 \\
\hline JAKI & 2 & $13 \%$ & 0 & $0 \%$ & 1 & $13 \%$ & 0 & $0 \%$ & 3 \\
\hline JDA & 1 & $7 \%$ & 0 & $0 \%$ & 0 & $0 \%$ & 3 & $9 \%$ & 4 \\
\hline JAMAL & 0 & $0 \%$ & 0 & $0 \%$ & 1 & $13 \%$ & 3 & $9 \%$ & 4 \\
\hline JIAB & 2 & $13 \%$ & 5 & $22 \%$ & 2 & $25 \%$ & 3 & $9 \%$ & 12 \\
\hline MRAAI & 0 & $0 \%$ & 1 & $4 \%$ & 1 & $13 \%$ & 2 & $6 \%$ & 4 \\
\hline JAI & 0 & $0 \%$ & 0 & $0 \%$ & 0 & $0 \%$ & 3 & $9 \%$ & 3 \\
\hline RAKI & 0 & $0 \%$ & 1 & $4 \%$ & 0 & $0 \%$ & 0 & $0 \%$ & 1 \\
\hline JAB & 0 & $0 \%$ & 2 & $9 \%$ & 0 & $0 \%$ & 0 & $0 \%$ & 2 \\
\hline JDM & 2 & $13 \%$ & 2 & $9 \%$ & 0 & $0 \%$ & 1 & $3 \%$ & 5 \\
\hline JKP & 2 & $13 \%$ & 2 & $9 \%$ & 2 & $25 \%$ & 5 & $14 \%$ & 11 \\
\hline JA & 1 & $7 \%$ & 3 & $13 \%$ & 0 & $0 \%$ & 0 & $0 \%$ & 4 \\
\hline JEB & 0 & $0 \%$ & 2 & $9 \%$ & 0 & $0 \%$ & 1 & $3 \%$ & 3 \\
\hline SRJ & 1 & $7 \%$ & 0 & $0 \%$ & 0 & $0 \%$ & 2 & $6 \%$ & 3 \\
\hline JFRA & 0 & $0 \%$ & 0 & $0 \%$ & 0 & $0 \%$ & 1 & $3 \%$ & 1 \\
\hline IJIMEFM & 0 & $0 \%$ & 0 & $0 \%$ & 0 & $0 \%$ & 1 & $3 \%$ & 1 \\
\hline AJAR & 0 & $0 \%$ & 1 & $4 \%$ & 0 & $0 \%$ & 0 & $0 \%$ & 1 \\
\hline JADEC & 0 & $0 \%$ & 0 & $0 \%$ & 0 & $0 \%$ & 1 & $3 \%$ & 1 \\
\hline JGR & 0 & $0 \%$ & 0 & $0 \%$ & 0 & $0 \%$ & 1 & $3 \%$ & 1 \\
\hline JCP & 0 & $0 \%$ & 0 & $0 \%$ & 0 & $0 \%$ & 1 & $3 \%$ & 1 \\
\hline JBE & 0 & $0 \%$ & 0 & $0 \%$ & 0 & $0 \%$ & 1 & $3 \%$ & 1 \\
\hline AAA & 0 & $0 \%$ & 0 & $0 \%$ & 0 & $0 \%$ & 1 & $3 \%$ & 1 \\
\hline \multirow[t]{2}{*}{ GMIJB } & 0 & $0 \%$ & 1 & $4 \%$ & 0 & $0 \%$ & 0 & $0 \%$ & 1 \\
\hline & 15 & & 24 & & 8 & & 34 & & 81 \\
\hline
\end{tabular}


Tabel 9. Klasifikasi jurnal berdasarkan metode penelitian

\begin{tabular}{|c|c|c|c|c|c|c|}
\hline \multirow[t]{2}{*}{ Nama jurnal } & \multicolumn{6}{|c|}{ Metode Penelitian } \\
\hline & Analytical & $\%$ & Review & $\%$ & Survey & $\%$ \\
\hline GMIJB & 0 & $0 \%$ & 0 & $0 \%$ & 1 & $10 \%$ \\
\hline JAK & 2 & $3 \%$ & 0 & $0 \%$ & 0 & $0 \%$ \\
\hline JAAI & 10 & $15 \%$ & 1 & $10 \%$ & 0 & $0 \%$ \\
\hline JAKI & 3 & $5 \%$ & 0 & $0 \%$ & 0 & $0 \%$ \\
\hline JDA & 4 & $6 \%$ & 0 & $0 \%$ & 0 & $0 \%$ \\
\hline JAMAL & 1 & $2 \%$ & 2 & $20 \%$ & 1 & $10 \%$ \\
\hline JIAB & 12 & $18 \%$ & 0 & $0 \%$ & 0 & $0 \%$ \\
\hline MRAAI & 4 & $6 \%$ & 0 & $0 \%$ & 0 & $0 \%$ \\
\hline JAI & 0 & $0 \%$ & 0 & $0 \%$ & 3 & $30 \%$ \\
\hline RAKI & 1 & $2 \%$ & 0 & $0 \%$ & 0 & $0 \%$ \\
\hline JAB & 1 & $2 \%$ & 0 & $0 \%$ & 1 & $10 \%$ \\
\hline JDM & 5 & $8 \%$ & 0 & $0 \%$ & 0 & $0 \%$ \\
\hline JKP & 10 & $15 \%$ & 0 & $0 \%$ & 1 & $10 \%$ \\
\hline JA & 4 & $6 \%$ & 0 & $0 \%$ & 0 & $0 \%$ \\
\hline JEB & 2 & $3 \%$ & 0 & $0 \%$ & 1 & $10 \%$ \\
\hline SRJ & 0 & $0 \%$ & 2 & $20 \%$ & 1 & $10 \%$ \\
\hline JFRA & 0 & $0 \%$ & 1 & $10 \%$ & 0 & $0 \%$ \\
\hline IJIMEFM & 1 & $2 \%$ & 0 & $0 \%$ & 0 & $0 \%$ \\
\hline AJAR & 1 & $2 \%$ & 0 & $0 \%$ & 0 & $0 \%$ \\
\hline JADEE & 0 & $0 \%$ & 1 & $10 \%$ & 0 & $0 \%$ \\
\hline JGR & 1 & $2 \%$ & 0 & $0 \%$ & 0 & $0 \%$ \\
\hline $\mathrm{JCP}$ & 1 & $2 \%$ & 0 & $0 \%$ & 0 & $0 \%$ \\
\hline PSBS & 3 & $5 \%$ & 1 & $10 \%$ & 1 & $10 \%$ \\
\hline JBE & 0 & $0 \%$ & 1 & $10 \%$ & 0 & $0 \%$ \\
\hline AAA & 0 & $0 \%$ & 1 & $10 \%$ & 0 & $0 \%$ \\
\hline Total & 66 & & 10 & & 10 & \\
\hline
\end{tabular}

\section{KESIMPULAN DAN SARAN}

\section{Kesimpulan}

Dalam studi ini, peneliti menganalisis 81 artikel yang membahas tentang praktik/aktivitas CSR yang dilakukan oleh perusahaan maupun pengungkapan informasi CSR perusahaan yan diterbitkan oleh 14 jurnal terakreditasi di Indonesia dan 10 jurnal internasional yang diklasifikasikan berdasarkan topik, metode, dan data kutipan pada 24 jurnal dari 2008 sampai tahun 2018. Mayoritas artikel tentang Coporate Social Responsibility di Indonesia diterbitkan di 3 Jurnal yaitu Jurnal Ilmiah Akuntansi dan Bisnis (JIAB) Universitas Udayana, Jurnal Akuntansi dan Auditing Indonesia (JAAI) Universitas Islam Indonesia, dan Jurnal Keuangan dan Perbankan (JKP) Universitas Brawijaya.
Topik yang paling banyak diteliti membahas mengenai ukuran perusahaan dan profitabilitas (sebagai variabel anteseden), kinerja perusahaan (sebagai variabel konsekuensi), serta pengujian dan penerapan praktik pengungkapan CSR. Hal ini sejalan dengan penelitian Gunawan (2018) yang menunjukkan bahwa variabel yangpaling banyak digunakan yangberhubungan dengan CSR adalah kinerja perusahaan. Gunawan melakukan penelitian mengenai perkembangan penelitian CSR di Indonesia pada periode pengamatan 2012-2016. Oleh karena itu, penelitian selanjutnya dapat meneliti lebih luas lagi untuk membahas kombinasi antara anteseden dan konsekuensi ataupun topik anteseden. Peneltian berikutnya juga dapat membahas mengenai topik yang masih kurang diteliti di Indonesia seperti risiko perusahaan, perpajakan, maupun topik lainnya. 
Selama 11 tahun metode penelitian yang paling banyak digunakan oleh peneliti di Indonesia untuk melakukan penelitian mengenai CSR adalah metode analytical yaitu sekitar 78\% (63 artikel) sedangkan 27\% lainnya menggunakan metode lain seperti literature review dan survey, sehingga penelitian selanjutnya sebaiknya dapat menggunakan metode yang masih jarang digunakan yaitu metode survey dan metode literature review untuk meneliti mengenai CSR di Indonesia.

\section{Saran}

Topik yang paling banyak diteliti dalam perkembangan penelitian CSR di Indonesia membahas mengenai ukuran perusahaan dan profitabilitas (sebagai variabel anteseden), kinerja perusahaan (sebagai variabel konsekuensi), serta pengujian dan penerapan praktik pengungkapan CSR. Untuk itu sebaiknya penelitian selanjutnya mempertimbangkan topik-topik yang masih kurang diteliti, seperti pengaruh era disrupsi industry 4.0 dimana menurut Lasi et al. (2014) terdapat perubahan signifikan berupamekanisasi dan otomatisasi, digitalisasi dan networking, dan miniaturisasi. Hal tersebut merupakan dorongan teknologi yang besar dalam praktik industri dan mengubah fundamental bisnis itu sendiri, yang tentunya akan berdampak pada stakeholder. Oleh karena itu untuk penelitian-penelitian selanjutnya pengaruh disrupsi pada CSR penting untuk diteliti.

Dalam dunia yang ideal, bisnis dan risiko akan menjadi entitas yang saling terpisah dari satu sama lain. Hal ini tentu saja tetap menjadi angan-angan dalam sebagian besar keadaan. Oleh karena itu perusahaan harus fokus mengidentifikasi cara untuk mengendalikan risiko sehingga dampak negatif bagi pemegang saham dapat diminimalkan. Dalam hal ini merupakan hal yang tepat untuk mengusulkan bahwa risiko dapat diatasi melalui tanggung jawab sosial perusahaan (CSR). Ditambah dengan adanya era disrupsi, perkembangan teknologi dan keterbukaan akses informasi merupakan hal yang penting bagi perusahaan maupun stakeholder, oleh karena itu akan banyak risiko-risiko baru yang muncul bagi perusahaan karena kesadaran masyarakat akan pentingnya keberlanjutan atau sustainability praktik bisnis semakin meningkat. Penelitian selanjutnya dapat menganalisis lebih lanjut mengenai hubungan maupun dampak praktik pengungkapan CSR perusahaan terhadap risiko perusahaan.
Di sisi lain, seiring dengan berkembangnya era disrupsi maka kemungkinan semakin terbukanya informasi perusahaan menjadi tinggi. Dalam hal ini, informasi mengenai pembayaran pajak juga penting untuk diperhatikan. Pembayaran pajak merupakan kontribusi perusahaan yang penting bagi masyarakat karena perusahaan perlu memperhatikan tanggung jawabnya terhadap peraturan dimana perusahaan itu berada guna menciptakan tata kelola yang baik. Oleh karena itu, praktik penghindaran pajak dapat menjadi aspek yang dapat diteliti lebih lanjut dari tanggung jawab sosial perusahaan (CSR) karena hal ini dapat memengaruhi keberlangsungan bisnis perusahaan.

\section{DAFTAR PUSTAKA}

Agusti RR, Rahman AF. 2011. Relevansi informasi akuntansi: peran pengungkapan csr dan dewan komisaris independen. Jurnal Akuntansi dan Auditing Indonesia 15(2): 121-129.

Amran A et al. 2017. Social responsibility disclosure in Islamic banks: a comparative study of Indonesia and Malaysia. Journal of Financial Reporting and Accounting 15(1): 99-115.

Anggraeni DY, Djakman CD. 2017. Slack Resources, Feminisme Dewan, dan Kualitas Pengungkapan Tanggung Jawab Sosial Perusahaan. Jurnal Akuntansi dan Keuangan Indonesia 14(1): 94118.

Anindita GN. 2014. Pengaruh Program Corporate Social Responsibility (CSR) Terhadap Kinerja Keuangan Pada Bank di Kota Surakarta [skripsi]. Surakarta: Fakultas Ekonomi dan Bisnis, Universitas Sebelas Maret.

Anugerah EG, Saraswati E, Andayani W. 2018. Quality of disclosure and corporate social responsibility reporting practices in Indonesia. Jurnal Akuntansi 22(3): 337-353.

Arifin J, Wardani EA. 2016. Islamic corporat social responsibility disclosure, reputasi, dan kinerja keuangan: Studi pada bank syariah di Indonesia. Jurnal Akuntansi \& Auditing Indonesia 20(1): $38-46$.

Arimbawa P, Wirakusuma MG. 2016. Pengaruh pengungkapan informasi corporate social responsibility, profitabilitas dan pembagian dividen pada harga saham. Jurnal Ilmiah Akuntansi dan Bisnis 14(1): 19-33.

Arli D, Tjiptono F. 2014. Does corporate social responsibility matter to consumers in Indonesia? 
Social Responsibility Journal 10(3): 537-549.

Armadi IW, Astika IBP. 2016. Pengaruh profitabilitas, leverage dan ukuran perusahaan pada nilai perusahaan melalui pengungkapan tanggung jawab sosial. Jurnal Ilmiah Akuntansi dan Bisnis 17(1): 233-256.

Bahuet C, Sopacua JA. n.d. SDGs in Indonesia: 2018 and beyond. https://www.id.undp.org. [Januari 2019]

Barus R, Maksum A. 2011. Analisis pengungkapan informasi csr dan pengaruhnya terhadap return saham. Jurnal Akuntansi dan Auditing Indonesia 15(1): 83-102.

Bulan AAAT, Astika IBP. 2014. Moderasi corporate social responsibility terhadap pengaruh kinerja keuangan pada nilai perusahaan. Jurnal Ilmiah Akuntansi dan Bisnis 8(2): 136-151.

Burke L, Logsdon JM. 1996. How corporate social responsibility pays off. Long Range Planning 29(4): 495-502.

Cahyonowati N, Darsono. 2013. Trend and determinants of csr disclosure in indonesia: a response of the Act No 40 (2007). Jurnal Dinamika Akuntansi 5(1): 67-78.

Cheng M, Christiawan YJ. 2011. Pengaruh pengungkapan corporate social responsibility terhadap abnormal return. Jurnal Akuntansi dan Keuangan 13(1): 24-36.

Darwis H. 2009. Ukuran perusahaan, profitabilitas, dan financial leverage terhadap pengungkapan tanggung jawab sosial perusahaan high profile di bei. Jurnal Keuangan dan Perbankan 13(1): 52-61.

Dewi AC, FitrianaA, Setiawan D. 2018. Perkembangan penelitian di bidang pengungkapan di Indonesia: Telaah konseptual. Jurnal Siasat Bisnis 22(1): $1-19$.

Djunaedi RR, Baga LM, Krisnatuti D. 2015. Efektivitas implementasi corporate social responsibility PT. ABC. Jurnal Aplikasi Bisnis dan Manajemen 1(2): 118-127.

Eriandani R. 2016. Pengaruh dimensi pengungkapan corporate social responsibility terhadap future institutional ownership. Jurnal Ekonomi dan Bisnis 17(1): 91-110.

Fahliyfi A. 2014. Analisis hubungan pengungkapan corporate social responsibility dengan kinerja keuangan pada perusahaan pertambangan yang terdaftar di bursa efek Indonesia. Media Riset, Akuntansi, Auditing \& Informasi 14(3): 49-72.

Famiola M, Adiwoso SA. 2016. Corporate social responsibility diffusion by multinational subsidiaries in Indonesia: organisational dynamic and institutional effect. Social Responsibility Journal 12(1): 117-129.

Fauziah K, Yudho P. 2013. Analisis pengungkapan tanggung jawab sosial perbankan syariah di indonesia berdasarkan islamic social reporting indeks. Jurnal Dinamika Akuntansi 5(1): 12-20.

Goyal A. 2005. Corporate social responsibility as a signaling device for foreign direct investment. International Journal of the Economics of Business 13(1): 145-163.

Gunawan J. 2017. Pengaruh corporate social responsibility dan corporate governance terhadap agresivitas pajak. Jurnal Akuntansi 21(3): 425436.

Gunawan J, Tin S. 2018. The development of corporate social responsibility in accounting research: evidence from Indonesia. Social Responsibility Journal 15(5): 671-688.

Handayani LD. 2012. Corporate social responsibility dan kinerja perbankan di indonesia. Jurnal Keuangan dan Perbankan 16(2): 318-328.

Handayani NT. 2012. Pengaruh Financial Ratio Terhadap Pertumbuhan Laba Dengan Pengungkapan Corporate Social Responsibility Sebagai Variabel Pemoderasi. Jurnal Dinamika Manajemen 1(2): 1-7.

Haryanto A. 2017. Tak Kuat Bau Limbah, Warga Kembali Demo PT Ultra Jaya. https://daerah. sindonews.com. [Januari 2019]

Hendarto KA. 2009. The implementation of corporate social responsibility (csr) in central java earthquake: a preliminary study on consumer belief, attitude, and purchase intention. Gadjah Mada International Journal of Business 11(3): 409-411.

Herawati N, Bandi B. 2019. Telaah riset perpajakan di indonesia: sebuah studi bibliografi. Jurnal Dinamika Akuntansi dan Bisnis 6(1): 103-120.

Hermawan S, Maf'ulah AN. 2014. Pengaruh kinerja keuangan terhadap nilai perusahaan dengan pengungkapan corporate social responsibility sebagai variabel pemoderasi. Jurnal Dinamika Akuntansi 6(2): 103-118.

Hesford J, Lee SH, Van der Stede WA, Young SM. 2007. Management Accounting: A Bibliographic Study, in: Handbook of Management Accounting Research. Amsterdam: Elsevier.

Hsu FJ, Chen YC. 2015. Is a firm's financial risk associated with corporate social responsibility? 
Management Decision 53(9): 2175-2199.

Ibrahim M, Solikahan EZ, Widyatama A. 2015. Karakteristik perusahaan, luas pengungkapan corporate social responsibility, dan nilai perusahaan. Jurnal Akuntansi Multiparadigma 6(1): 99-106.

Isnalita, Narsa IM. 2017. CSR disclosure, customer loyalty, and firm values (study at mining company listed in Indonesia stock exchange). Asian Journal of Accounting Research 2(2): 8-14.

Joseph C et al. 2016. A comparative study of anticorruption practice disclosure among Malaysian and Indonesian Corporate Social Responsibility (CSR) best practice companies. Journal of Cleaner Production 112(4): 2896-2906.

Junaidi J. 2014. Analisis pengungkapan CSR perbankan syariah di Indonesia berdasarkan islamic social reporting index. Jurnal Akuntansi dan Investasi 16(1): 75-85.

Kementerian Lingkungan Hidup dan Kehutanan. 2018. Indonesia bangun optimisme konsumsi dan produksi yang berkelanjutan, demi percepatan pencapaian SDGs. http://www.menlhk.go.id. [Januari 2019]

Kusumayanti NKR, Astika IBP. 2016. Corporate social responsibility sebagai pemediasi pengaruh ukuran perusahaan, profitabilitas dan leverage pada nilai perusahaan. Jurnal Ilmiah Akuntansi dan Bisnis 15(1): 549-583.

Larasati DD, Hadi S. 2011. Pengaruh kondisi keuangan perusahaan terhadap pengungkapan tanggung jawab sosial. Jurnal Akuntansi dan Auditing Indonesia 15(2): 178-189.

Lindawati ASL, Puspita ME. 2015. Corporate social responsibility: implikasi stakeholder dan legitimacy gap dalam peningkatan kinerja perusahaan. Jurnal Akuntansi Multiparadigma 6(1): 157-174.

Mai MU. 2017. Mediation of corporate social responsibility and profitability on the influences of gcg mechanisms to the firm value. Jurnal Keuangan dan Perbankan 21(2): 253-264.

Makhfudloh F, Herawati N, Wulandari A. 2018. Pengaruh corporate social responsibility terhadap perencanaan agresivitas pajak. Jurnal Akuntansi dan Bisnis 18(1): 48-60.

Maraya AD, Yendrawati R. 2016. Pengaruh corporate governance dan corporate social responsibility disclosure terhadap tax avoidance: studi empiris pada perusahaan tambang dan CPO. Jurnal
Akuntansi \& Auditing Indonesia 20(2): 147159.

Marfuah, Cahyono YD. 2011. Karakteristik perusahaan dan pengungkapan tanggung jawab sosial. Jurnal Akuntansi \& Auditing Indonesia 15(1): 103-119.

MayangsariS,AminahA. 2013.Pengaruhpengungkapan corporate social responsibility terhadap earning response coefficient. Media Riset Akuntansi, Auditing dan Informasi 13(1): 111-137.

Mirfazli E. 2008. Corporate social responsibility (CSR) information disclosure by annual reports of public companies listed at Indonesia Stock Exchange (IDX). International Journal of Islamic and Middle Eastern Finance and Management 1(4): 275-284.

Mittal RK, Sinha N, Singh A. 2008. An analysis of linkage between economic value added and corporate social responsibility. Management Decision 46(9): 1437-1443.

Muchlis S, Sukirman AS. 2016. Implementasi maqashid syariah dalam Corporate Social Responsibility di PT Bank Muamalat Indonesia. Jurnal Akuntansi Multiparadigma 7(1): 120-130.

Murwaningsari E. 2009. Hubungan corporate governance, corporate social responsibilities dan corporate financial performance dalam satu continuum. Jurnal Akuntansi dan Keuangan 11(1): 30-41.

Nahar A. 2015. analisis praktik corporate social responsibility perusahaan furniture di Kabupaten Jepara. Jurnal Akuntansi dan Investasi 13(2): 116-129.

Nasution RM, Adhariani D. 2016. Simbolis atau Substantif? Analisis Praktik Pelaporan CSR dan Kualitas Pengungkapan. Jurnal Akuntansi dan Keuangan Indonesia 13(1): 23-51.

Nugraheni P, Permatasari D. 2016. Perusahaan syariah dan pengungkapan corporate social responsibility: Analisis pengaruh faktor internal dan karakteristik perusahaan. Jurnal Akuntansi \& Auditing Indonesia 20(2): 136-146.

Nussy TM. 2017. Corporate governance dan etnisitas terhadap pengungkapan corporate social responsibility. Jurnal Keuangan dan Perbankan 17(1): 1-10.

Nussy TM. 2014. Pengungkapan tanggung jawab sosial perbankan di Indonesia. Jurnal Keuangan dan Perbankan 18(2): 329-334.

Oeyono, J., Samy, M., Bampton, R., 2011. An examination of corporate social responsibility 
and financial performance: a study of the top 50 Indonesian listed corporations. Journal of Global Responsibility 2(1): 100-112.

Palupi ID, Wulandari D, Safitri DA. 2017. Pengaruh pengungkapan informasi proyeksi dan tanggung jawab sosial perusahaan terhadap koefisien respon laba. Riset Akuntansi dan Keuangan Indonesia 2(1): 91-101.

Pebriana KUS, Sukartha IM. 2012. Pengaruh profitabilitas, leverage, umur perusahaan, komposisi dewan direksi dan kepemilikan institusional pada pengungkapan corporate social responsibility di BEI. Jurnal Dinamika Manajemen 1(2): 1-16.

Prakasa S, Astika IBP. 2017. Pengaruh leverage, profitabilitas, dan kepemilikan manajemen pada corporate social responsibility disclosure perusahaan pertambangan. Jurnal Ilmiah Akuntansi dan Bisnis 18(1): 189-215.

Prihatiningtias YW. 2012. Corporate Social Responsibility (CSR) and managing ethical cultures. Jurnal Akuntansi Multiparadigma 3(1): 155-160.

Putra BD, Wirakusuma MG. 2015. Pengaruh pengungkapan corporate social responsibility pada nilai perusahaan dengan profitabilitas sebagai pemoderasi. Jurnal Ilmiah Akuntansi dan Bisnis 13(2): 461-475.

Putra CGB, Rasmini NK, Astika IBP. 2013. Pengaruh corporate social responsibility pada price to book value dengan corporate governance sebagai variabel moderasi. Jurnal Ilmiah Akuntansi dan Bisnis 2(5): 339-353.

Rahman A, Widyasari KN. 2008. The analysis of company characteristic influence toward csr disclosure: empirical evidence of manufacturing companies listed in JSX. Jurnal Akuntansi \& Auditing Indonesia 12(1): 25-35.

Rahmawati R. 2018. Deconstructing the concept of corporate social responsibility: social investment on Luwu Indigeous Society. Journal of Accounting and Investment 19(2): 233-265.

Ratih IDA, Damayanthi IGAE. 2016. Kepemilikan manajerial dan profitabilitas pada nilai perusahaan dengan pengungkapan tanggung jawab sosial sebagai variabel pemoderasi. Jurnal Ilmiah Akuntansi dan Bisnis 14(2): 1510-1538.

Raynard P, Forstater M. 2002 Corporate Social Responsibility: Implications for Small and Medium Enterprises in Developing Countries. Vienna: UNIDO and the World Summit on
Sustainable Development.

Restuningdiah N. 2010. Kinerja keuangan terhadap ROA melalui corporate social responsibility disclosure. Jurnal Keuangan dan Perbankan 14(2): 191-204.

Restuningdiah N. 2010b. Mekanisme GCG dan pengungkapan tanggung jawab sosial terhadap koefisien respon laba. Jurnal Keuangan dan Perbankan 14(3): 377-390.

Restuti MMD, Nathaniel C. 2012. Pengaruh pengungkapan corporate social responsibility terhadap earning response coefficient. Jurnal Dinamika Manajemen 3(1): 40-48.

Riantani S, Nurzamzam H. 2015. Analysis of company size, financial leverage, and profitability and its effect to corporate social responsibility disclosure. Jurnal Dinamika Manajemen 6(2): 203-213.

Setiyawati H, Basar YS. 2017. Pengaruh pengungkapan corporate social responsibility dan penerapan good corporate governance terhadap tingkat profitabilitas (studi empiris pada perusahaan sektor pertambangan yang terdaftar di BEI). Jurnal Akuntansi 21(3): 351-360.

Sindhudiptha INSY, Yasa GW. 2013. Pengaruh corporate social responsibility pada kinerja keuangan perusahaan dan implikasinya terhadap nilai perusahaan. Jurnal Ilmiah Akuntansi dan Bisnis 4(2): 388-405.

Sjauw-Koen-Fa AR, Blok V, Omta OSWF. 2018. Exploring the integration of business and CSR perspectives in smallholder souring: Black soybean in Indonesia and tomato in India. Journal of Agribusiness in Developing and Emerging Economies 8(4): 656-677.

Soedaryono B, Riduifana D. 2017. Pengaruh GCG terhadap nilai perusahaan melalui corporate social responsibility. Media Riset Akuntansi, Auditing dan Informasi 13(1): 1-33.

Sofiamira NA, Haryono NA. 2017. Capital expenditure, leverage, good corporate governance, corporate social responsibility: pengaruhnya terhadap nilai perusahaan. Jurnal Ekonomi dan Bisnis 20(2): 191-214.

Sofyani H, Ulum I, Syam D, Latifah SW. 2012. Islamic social reporting index sebagai model pengukuran kinerja sosial perbankan syariah (studi komparasi Indonesia dan Malaysia). Jurnal Dinamika Akuntansi 4(1): 36-46.

Suaryana A. 2012. Faktor-faktor yang mempengaruhi kebijakan pengungkapan tanggung jawab sosial 
dan lingkungan pada perusahaan manufaktur di bursa efek indonesia. Jurnal Ilmiah Akuntansi dan Bisnis 7(1): 1-20.

Suparjan A, Mulya AS. 2012. Pengaruh kinerja sosial dan kinerja keuangan perusahaan dengan pengungkapan corporate social responsibility sebagai variabel intervening terhadap nilai perusahaan. Media Riset Akuntansi, Auditing dan Informasi 12(3): 27-57.

Suprianto E, Setiawan D. 2017. Manajemen laba di indonesia: studi ssebuah bibliograpi. Jurnal Keuangan dan Perbankan 21(2): 287-301.

Suryaningsum $\mathrm{S}$ et al. 2016. The influence of banking corporate social responsibility through financial performance. Jurnal Keuangan dan Perbankan 20(3): 468-478.

Suryaputra FAG, Bandi B, Setiawan D. 2017. Perkembangan Penelitian Kinerja Perbankan di Indonesia. Jurnal Akuntansi dan bisnis 17(2): 88-99.

Susianti MNL, Yasa GW. 2013. pengaruh kinerja keuangan terhadap nilai perusahaan dengan pemoderasi good corporate governance dan corporate social resposibility. Jurnal Ilmiah Akuntansi dan Bisnis 3(1): 73-91.

Susilawati CDK, Tin S, Agustina L. 2014. Faktorfaktor fundamental dan jenis industri terhadap corporate social responsibility serta dampaknya terhadap harga saham. Jurnal Keuangan dan Perbankan 18(3): 384-395.

Suteja J, Mayasari AN. 2017. Is investment policy value-enhancing through CSR Disclosure? Jurnal Keuangan dan Perbankan 21(4): 587596.

Tempo.co. 2010. Burger king boikot minyak sawit sinar mas. Tempo.Co. https://bisnis.tempo.co. [Jan 2019]

Trisnawati R. 2012. Pengukuran tanggung jawab sosial perusahaan perbankan syariah di Indonesia. Jurnal Akuntansi \& Auditing Indonesia 16(2): 103-121.

Waagstein PR. 2011. The mandatory corporate social responsibility in indonesia: problems and implications. Journal of Business Ethics 98(3): 455-466.
Wahyudi I. 2017. CSR disclosure - legitimacy dan perubahan retorika. Jurnal Akuntansi \& Auditing Indonesia 21(2): 70-80.

Wardoyo, Veronica TM. 2013. Pengaruh good corporate governance, corporate social responsibility \& kinerja keuangan terhadap nilai perusahaan. Jurnal Dinamika Manajemen 4(2): 132-149.

Welker MA. 2009. "CORPORATE security begins in the community": mining, the corporate social responsibility industry, and environmental advocacy in Indonesia. Cultural Anthropology 24(1): 142-179.

Witjaksono RB, Djaddang S. 2018. Valuasi kesadaran lingkungan, corporate social responsibility terhadap kualitas laba dengan moderasi komite audit. Jurnal Ekonomi dan Bisnis 21(1): 97114.

Wulandari AA, Ramantha IW, Wirakusuma MG. 2016. Dampak moderasi profitabilitas terhadap pengaruh corporate social responsibility pada nilai perusahaan manufaktur. Jurnal Ilmiah Akuntansi dan Bisnis 5(7): 1889-1918.

Yanti Y. 2017. Pengaruh corporate social responsibility dan environmental performance terhadap kinerja keuangan bumn dan non bumn yang terdaftar di bursa efek Indonesia 2009-2012. Jurnal Akuntansi 19(2): 242-259.

Yasa NNK, Sukaatmadja PG, Widagda IGNJA, Putra IPAA. 2015. Corporate social responsibility terhadap loyalitas nasabah yang dimediasi oleh citra perusahaan. Jurnal Keuangan dan Perbankan 9(1): 137-148.

Yudhiyati R, Solihin M. 2016. Apakah pengungkapan sosial memediasi hubungan antara variabel kontekstual dan kinerja keuangan? bukti empiris pada bank syariah. Jurnal Akuntansi \& Auditing Indonesia 20(2): 85-98.

Yuliana R, Purnomosidhi B, Sukoharsono EG. 2008. Pengaruh karakteristik perusahaan terhadap pengungkapan csr dan dampaknya terhadap reaksi investor. Jurnal Akuntansi dan Keuangan Indonesia 5(2): 245-276. 